\title{
PEMBERDAYAAN IBU-IBU RUMAH TANGGA DENGAN KETERAMPILAN MEMBUAT SERBUK JAHE INSTAN
}

\author{
Oleh: \\ KKN PPuN 62 Bojonegoro (Unit I.A.I) \\ Universitas Ahmad Dahlan Yogyakarta
}

\section{Ringkasan}

KKN Reguler Pemberdayaan dan Pembelajaran untuk Negeri (PpuN) merupakan KKN yang diharapkan mampu memberdayakan masyarakat untuk mampu mengatasi masalah-masalah yang ada. Program - program yang disusun diracang sedemikian rupa untuk mampu menggerakkan masyarakat itu sendiri. Memaksimalkan potensi lokal yang ada merupakan salah satu tujuan dari program-program yang dibuat. Salah satu dari program pemberdayaan masyarakat ialah pembuatan serbuk jahe instan. Serbuk jahe instan merupakan suatu produk olahan dari jahe yang dikristalkan dengan cara direbus dengan air dan gula. Besarnya potensi kesehatan dan kimia/gizi yang terkandung dalam jahe dapat dimanfaatkan untuk membuat produk baru yaitu minuman kesehatan berbentuk serbuk/instan yang lebih praktis dan efisien. Setelah pelatihan ini diharapkan mampu menjadi peluang usaha bagi ibu rumah tangga sehingga secara tidak langsung dapat meningkatkan perekonomian dan kesejahteraan masyarakat Desa Kalirejo, Bojonegoro.

Kata kunci : KKN PpuN, Serbuk Jahe Instan, Bojonegoro.

\begin{abstract}
KKN Reguler Pemberdayaan dan Pembelajaran untuk Negeri (PpuN) is a service that is expected to empower the community to be able to overcome the problems that exist. The programs are structured in such a way as to be able to mobilize the community itself. Maximizing existing local potential is one of the goals of the programs created. One of the community empowerment programs is the making of Instant ginger powder. Instant ginger powder is a processed product of ginger crystallized by boiling it with water and sugar. The amount of potential health and chemistry I nutrition contained in ginger can be utilized to create a new product that is powder / instant health drink that is more practical and efficient. After this training is expected to be a business opportunity for housewives so that indirectly can improve economy and prosperity of society Kalirejo Village, Bojonegoro.
\end{abstract}

Keyword: KKN PPuN, Instan Ginger Powder, Bojonegoro.

\section{A. PENDAHULUAN}

\section{Latar Belakang}

Mobilitas masyarakat yang semakin tinggi memerlukan kondisi kesehatan yang optimal. Kondisi kesehatan tubuh tentunya tidak bisa lepas dari konsumsi makanan yang sehat. Banyaknya penyakit yang ditimbulkan karena cara mengkonsumsi makanan yang salah ataupun keamanan makanan yang tidak terjaga menyebabkan masyarakat cenderung bersikap hati-hati.

Saat ini banyak makanan dan minuman yang ditawarkan sebagai produk suplemen yang dapat meningkatkan kesehatan tubuh jika dikonsumsi. Minuman kesehatan merupakan minuman yang mengandung unsur-unsur zat gizi atau non zat gizi dan jika dikonsumsi dapat memberikan pengaruh posistif terhadap kesehatan tubuh (Muchtadi, 1996). Minuman kesehatan sebagai salah satu produk yang sudah dikenal masyarakat, 
banyak dijumpai di pasaran dengan berbagai merek dan bentuk, seperti dalam bentuk cair, serbuk instan ataupun tablet. Kecenderungan masyarakat saat ini adalah lebih suka menggunakan produk yang kemasan dan penyajiannya lebih praktis dan cepat, karena tidak perlu membutuhkan banyak waktu dalam mempersiapkannya.

Salah satu contoh minuman kesehatan yang dapat dijumpai adalah minuman instan ekstrak jahe, dimana produk tersebut umumnya dibuat dengan mengambil sari dari rimpang jahe kemudian dilakukan pengolahan lanjut. Kebanyakan produk tersebut dijumpai dalam bentuk serbuk, di samping ada beberapa yang dibuat dalam bentuk tabled maupuncair.

Pemanfaatan dalam bidang kesehatan, zat aktif berupa zingeron dan senyawa antioksidan lain yang terkandung dalam jahe dapat digunakan bumbu masak, pemberi aroma dan rasa pada makanan seperti roti, kue, biskuit, kembang gula dan berbagai minuman. Jahe juga digunakan dalam industri obat, minyak wangi dan jamu tradisional. Jahe muda dimakan sebagai lalaban, diolah menjadi asinan dan acar.

Besarnya potensi kesehatan dan kimia/gizi yang terkandung dalam jahe, menggugah peneliti untuk mencoba menuangkan ide dan inovasi menciptakan produk baru yaitu minuman kesehatan berbentuk serbuk/instan dengan memanfaatkan jahe. Ide pembuatan ini didasarkan pada sifat bahan yang memungkinkan untuk dapat dibuat minuman instan dengan mengacu pada proses pembuatan minuman instan secara umum.

Khasiat minuman instan ekstrak jahe dan untuk menciptakan produk yang praktis dan efisien, sehingga diharapkan diperoleh manfaat kesehatan. Hal ini didasari juga oleh tingginya kebutuhan masyarakat akan kesehatan dan kecenderungan masyarakat untuk mengkonsumsi minuman kesehatan yang lebih praktis dan efisien, sehingga diperlukan kemudahan untuk mendapatkannya.

Di samping itu, bahan pembuatannya dapat diperoleh dengan mudah dan harganyapun terjangkau oleh masyarakat, karena ketersediaanya cukup banyak di pasar atau di lingkungan masyarakat sekitar. Bahan yang dimaksud adalah jahe, dan gula yang telah dipilih dengan kualitas terbaik. Hal yang mendasari penggunaan minuman instan adalah minuman instan lebih praktis karena hanya menyeduh serbuk dengan air hangat kemudian diminum. Serbuk minuman instan dapat digunakan dalam jangka lama karena berbentuk serbuk sehingga tahan dalam penyimpanan.

\section{B. KERANGKA TEORI}

\section{Jahe}

Jahe (Zingiber officinale), adalah tanaman rimpang yang sangat populer sebagai rempah-rempah dan bahan obat. Rimpangnya berbentuk jemari yang menggembung di ruas-ruas tengah. Rasa dominan pedas disebabkan senyawa keton bernama zingeron.

Jahe (Zingiber officinale Rosc) adalah tanaman yang tumbuh tegak dengan tinggi 30-60 cm. Daun tanaman jahe berupa daun tunggal, berbentuk lanset dan berujung runcing. Mahkota bunga berwarna ungu, berbentuk corong dengan panjang $2-2,5 \mathrm{~cm}$. Sedangkan buah berbentuk bulat panjang berwarna cokelat dengan biji berwarna hitam.

Berdasarkan ukuran dan warna rimpangnya, jahe dapat dibedakan menjadi 3 (tiga) varietas, yaitu jahe besar (jahe gajah), jahe kecil (jahe emprit), dan jahe merah (jahe sunti). 
Jahe merah dan jahe kecil banyak dimanfaatkan sebagai bahan obat-obatan. Sedangkan jahe besar dimanfaatkan sebagai bumbu masak (Matondang, 2005).

Jahe memiliki kandungan aktif yaitu oleoresin. Oleoresin adalah minyak dan damar yang merupakan campuran minyak atsiri sebagai pembawa aroma dan sejenis damar sebagai pembawa rasa. Oleoresin jahe mengandung komponen gingerol, paradol, shogaol, zingerone, resin dan minyak atsiri. Persenyawaan zingerone tidak dalam bentuk persenyawaan keton bebas, melainkan dalam bentuk persenyawaan aldehid alifatis jenuh, terutama senyawa n-heptanal (Ravindran et al., 2005).

Secara tradisional ekstrak jahe digunakan antara lain sebagai obat sakit kepala, obat batuk, masuk angin, untuk mengobati gangguan pada saluran pencernaan, stimulansia, diuretik, rematik, menghilangkan rasa sakit, obat anti-mual dan mabuk perjalanan, karminatif (mengeluarkan gas dari perut) dan sebagai obat luar untuk mengobati gatal digigit serangga, keseleo, bengkak, serta memar (Shukla, 2007).

Berbagai penelitian membuktikan bahwa jahe mempunyai sifat antioksidan dan antikanker. Beberapa komponen utama dalam jahe seperti gingerol, shogaol dan gingerone memiliki antioksidan di atas Vitamin E (Kikuzaki dan Nakatani, 1993). Selain itu, jahe mampu menaikkan aktivitas salah satu sel darah putih, yaitu sel natural killer (NK) dalam melisis sel targetnya, yaitu sel tumor dan sel yang terinfeksi virus. (Zakaria et al., 1999).

Berbagai penelitian membuktikan bahwa jahe mempunyai sifat antioksidan. Beberapa komponen utama dalam jaheseperti gingerol, shogaol, dan gingeron memiliki aktivitas antioksidan di atas vitamin E (Kikuzaki dan Nakatani 1993). Selain itu jahe juga mempunyai aktivitas antiemetik dan digunakan untuk mencegah mabuk perjalanan. Radiati et al. (2003) menyatakan bahwa konsumsi ekstrak jahe dalam minuman fungsional dan obat tradisional dapat meningkatkan ketahanan tubuh dan mengobati diare. Hasil penelitian menunjukkan bahwa ekstrak jahe dapat meningkatkan daya tahan tubuh yang direfleksikan dalam sistem kekebalan, yaitu memberikan respons kekebalan inang terhadap mikroba pangan yang masuk ke dalam tubuh.

\section{Kebutuhan Masyarakat Terhadap Minuman Kesehatan (Jamu Tradisional)}

Di Indonesia, masih banyak orang yang tergolong fanatic mengkonsumsi jamu untuk menghilangkan rasa sakit atau peningkat stamina tubuh. Hal ini telah berlangsung selama belasan tahun dan telah menjadi tradisi yang dilakukan secara turun temurun. Bagi mereka yangsudah terbiasa, jamu tradisional dianggap lebih mujarab dan lebih aman dibandingkan dengan obat-obatan sintetis.

Ide pengembangan teknik pengolahan ini didasarkan pada sifat bahan yang dapat dibuat minuman kesehatan berbentuk serbuk, sehingga diharapkan dapat mengangkat potensi ekonomi dan potensi kesehatan secara optimal pada tanaman tersebut. Keunggulan teknik ini yaitu dapatmenghasilkan produk minuman kesehatan yang diharapkan mempunyai manfaat ganda dalam bidang kesehatan. Manfaat ganda ini didukung oleh karena adanya kandungan senyawa kimia dan zat aktif penting dalam kedua bahan yang diperlukan dalam metabolisme tubuh, sehingga sangat baik untuk dikonsumsi sebagai produk minuman yang menyehatkan. Disamping itu, wujudnya yang berbentuk serbuk 
instan akan memberikan kemudahan untuk dikonsumsi karena hanya menyeduh air kemudian diminum serta tahan dalam masa simpan

\section{Pemberdayaan Dan Partisipasi}

Pemberdayaan dan partisipasi merupakan hal yang menjadi pusat perhatian dalam proses pembangunan belakangan ini di berbagai Negara. Kemiskinan yang terus melanda dan menggerus kehidupan umat manusia akibat resesi internasional yang terus bergulir dan proses restrukturisasi, agen nasional-internasional, serta negara-negara setempat menunjukkan perhatian yang sangat besar terhadap strategi partisipasi masyarakat sebagai sarana proses percepatan pembangunan manusia. Karena itu, perlu ditekankan peningkatan tentang pentingnya pendekatan alternative berupa pendekatan pembangunan yang diawali oleh proses pemberdayaan masyarakat local (Craig dan Mayo, 1995).

Pemberdayaan dan partisipasi merupakan strategi yang sangat potensial dalam rangka meningkatkan ekonomi, social, dan transformasi budaya. Proses ini, pada akhirnya, akan dapat menciptakan pembangunan yang lebih berpusat pada rakyat. Cara yang terbaik untuk mengatasi masalah pembangunan adalah membiarkan semangat wiraswasta tumbuh dalam kehidupan masyarakat yang berarti berani mengambil risiko, berani bersaing, menumbuhkan semangat untuk menemukan hal-hal baru (inovasi) melalui partisipasi masyarakat.

\section{METODE PENGABDIAN}

\section{Tipe Dan Dasar Program}

Program kerja yang dilaksanakan oleh mahasiswa Kuliah Kerja Nyata Reguler PpuN periode 62 berdasarkan masukan dari masyarakat. Masukan-masukan tersebut merupakan kebutuhan dari masyarakat sendiri. Dalam melaksanakan program tersebut, terlebih dahulu dibutuhkan beberapa strategi dan pendekatan kepada masyarakat dalam menggali dan menyusun program kerja.

Adapun strategi dan pendekatan yang digunakan adalah:

a. Observasi.

Observasi dilakukan selama kurang lebih tujuh hari untuk meninjau secara langsung kondisi geografis maupun karakteristik masyarakat yang ada. Hal yang dislakukan adalah mengadakan silaturahmi baik pada pendekatan persuasif personal maupun kelompok masyarakat, sasarannya adalah seluruh masyarakat,tokoh masyarakat, tokoh agama di lingkungan Kalirejo. Hal tersebut merupakan tahapan sosialiasi dan menggali informasi terutama yang berhubungan dengan keadaan desa Kalirejo.

b. Wawancara

Teknik pengumpulan data melalui tanya jawab responden maupun informan untuk mendapatkan informasi yang didapatkan.

\section{Pelaksanaan Program}

a. Waktu dan Tempat 
Diterbitkan oleh Lembaga Pengabdian kepada Masyarakat

Universitas Ahmad Dahlan Yogyakarta

Pembuatan serbuk jahe instan ini dilakukan pada pekan ke $3 \mathrm{KKN}$ reguler, yaitu pada tanggal 20 Agustus 2017 bertempat di halaman rumah salah satu warga RT 05.

b. Bahan

\begin{tabular}{|l|l|l|}
\hline \multicolumn{1}{|c|}{ Bahan } & \multicolumn{1}{|c|}{ 1 Resep } & \multicolumn{1}{c|}{$1 / 2$ Resep } \\
\hline Jahe emprit & $250 \mathrm{gr}$ & $125 \mathrm{gr}$ \\
\hline Gula pasir & $500 \mathrm{gr}$ & $250 \mathrm{gr}$ \\
\hline Air & $250 \mathrm{ml}$ & $125 \mathrm{ml}$ \\
\hline
\end{tabular}

c. Cara Pembuatan

1. Jahe diblender, saring sari jahe.

2. Rebus sari jahe, gula dan air.

3. Didihkan sambil diaduk terus menerus, pastikan api pada kompor stabil dan tidak terlalu besar

$\mathbf{S}$

\section{PEMBAHASAN}

Wilayah Bojonegoro memiliki iklim yang cukup panas namun tidak kekeringan terutama di desa Kalirejo karena di lewati oleh sungai Bengawan, sehingga cocok untuk ditanami jahe. Tanaman jahe yang mudah tumbuh di sekitar tempat tinggal warga dapat diolah sehingga dapat meningkatkan nilai harga jual ketimbang hanya berbentuk jahe tanpa diolah terlebih dahulu.

Pelatihan ini diikuti oleh 25 peserta ibu-ibu RT 05. Kegiatan tersebut disambut antusias oleh peserta dari awal proses pembuatan hingga akhir. Proses tersebut dimulai dari penghalusan jahe emprit menggunakan blender. Jahe yang sudah halus disaring, kemudian diambil sarinya. Tahap akhir dalam pebuatan serbuk jahe instan ini yaitu mendidihkan semua bahan hingga airnya menguap hingga menjadi kristal-kristal halus.

\section{E. KESIMPULAN DAN SARAN}

\section{Kesimpulan}

Besarnya potensi kesehatan dan kimia/gizi yang terkandung dalam jahe dapat dimanfaatkan untuk membuat produk baru yaitu minuman kesehatan berbentuk serbuk/instan yang lebih praktis dan efisien. Pengolahan jahe menjadi serbuk instan juga dapat meningkatkan daya jual dari jahe. Sehingga hal ini dapat memberikan peluang usaha bagi ibu rumah tangga dan secara tidak langsung dapat meningkatkan perekonomian dan kesejahteraan masyarakat.

\section{Saran}

a. Perlu adanya program berkelanjutan untuk mengembangkan program ini.

b. Dukungan pihak-pihak seperti pemerintahan untuk membantu program ini. 
c. Masyarakat terus mau berinovasi dan prouktif dalam mengembangkan segala potensi yang ada disekitarnya.

\section{DAFTAR PUSTAKA}

Id.wikipedia.org/wiki/jahe

https://umiarsih.wordpress.com/2013/10/08/pembuatan-minuman-sehat-instan-Jaheinstan/

Mrwindu dot com. 2011.minuman jamu instan "jahe putih instan" http://www.mrwindu.com/2011/05/minuman-jamu-instan-jahe-putih-instan.html

Radiati, L.E., E.P. Nabet, P. Franck, B. Nabet, J.Capiaumont, D. Fardiaz, F.R. Zakaria, I.Sudirman, dan R.D. Haryadi. 2003. Pengaruhekstrak diklormetan jahe (Zingiberofficinale) terhadap pengikatan toksin koleraB-subunit conjugasi (FITC) pada reseptor selhibridoma LV dan Caco-2. Jurnal Teknologidan Industri Pangan XIV (1): 59-67.

Safadajahe.blogsome.com/jahe

Zakaria, F.R. dan T.M. Rajab. 1999. Pengaruh ekstrak jahe (Zingiber officinale Roscoe) terhadap produksi radikal bebas makrofagmencit sebagai indikator imunostimulansecara in vitro. Persatuan Ahli PanganIndonesia (PATPI). Prosiding SeminarNasional Teknologi Pangan: 707-716.

Zakaria, F.R., Y. Wiguna, dan A. Hartoyo. 1999. Konsumsi sari jahe (Zingiber officinaleRoscoe) meningkatkan aktivitas sel naturalkiller pada mahasiswa pesantren Ulil Albaabdi Bogor. Buletin Teknologi Industri PanganX (2): 40-46. Teknologi pembuatan jahe instant departemen pertanian bptp Jakarta 